\title{
Osteopenija nedonošenčka
}

\section{Metabolic bone disease of prematurity}

Nina Majoranc, Aneta Soltirovska Šalamon

\section{Izvleček}

Presnovna bolezen kosti (PBK) pri novorojenčku - osteopenija je bolezen, ki je pretežno posledica neustrezne mineralizacije kosti, na njen razvoj pa vplivajo tudi genetski, mehanski in okoljski dejavniki. Po rojstvu se namreč ustavi prehajanje mineralov od matere preko posteljice do otroka, zato je novorojenček za zagotavljanje potreb po mineralih v celoti odvisen od enteralnega ali parenteralnega vnosa. Po drugi strani pa fiziološka prilagoditev kosti na zunajmaterično življenje vodi v povečanje resorpcije kosti, tj. fiziološko osteopenijo. Dohitevanje mineralizacije pri nedonošenčkih (angl. catch up mineralisation) se zaključi do konca prvega leta starosti, vendar vprašanje dolgoročnih posledic na doseganje maksimalne kostne mase pri tej skupini otrok ostaja odprto. Najboljši pristop k zmanjševanju pogostosti PBK je preprečevanje, ki temelji na presejanju novorojenčkov, izpostavljenih tveganju PBK. Zgodnja optimalna parenteralna in enteralna prehrana, ustrezna preskrba s vitaminom $D$ in odstranjevanje dejavnikov tveganja so ključni za preprečevanje razvoja osteopenije novorojenčka. Biokemijski presejalni testi, ki vključujejo serumsko raven fosfata in alkalne fosfataze $v$ kombinaciji z vrednostmi izločenih mineralov $v$ urinu, so koristni kazalniki presnove kosti. Dvoenergijska rentgenska absorpciometrija in kvantitativna ultrazvočna metoda sta komplementarni metodi merjenja mineralne kostne gostote pri novorojenčkih. V prispevku obravnavamo klinične značilnosti in patofiziologijo PBK, njeno diagnostično opredelitev in praktična priporočila v zvezi z obravnavo.

Ključne besede: presnovna bolezen kosti, osteopenija, nedonošenček.

\begin{abstract}
Metabolic bone disease (MBD) in the newborn - osteopenia, is a disease that occurs mainly as a result of inadequate bone mineralisation, and its development is also influenced by genetic, mechanical and environmental factors. After birth, the transfer of minerals from the mother through the placenta ceases, so the newborn is completely dependent on enteral or parenteral intake to meet his/her needs. On the other hand, the physiological adaptation of bone to extrauterine life leads to an increase in bone resorption - physiological osteopenia. Catch-up mineralisation in premature infants is achieved by the end of the first year of life, although the question of the long-term consequences for achieving maximum bone mass in this group of children remains open. The best approach to reducing the incidence of MBD is prevention based on screening newborns at risk for MBD. Early optimal parenteral and enteral nutrition, adequate supply of vitamin $D$, and removal of risk factors are key to preventing the development of neonatal osteopenia. Biochemical screening tests: serum phosphorus levels, alkaline phosphatase in combination with the values of excreted minerals in the urine are useful indicators of bone metabolism. Dual-energy X-ray absorptiometry and quantitative ultrasound are complementary methods for measuring bone mineral density in newborns. This article discusses the clinical features and pathophysiology of MBD, the diagnostic process and practical treatment recommendations.
\end{abstract}

Key words: metabolic bone disease, osteopenia, preterm newborn. 


\section{Uvod}

Presnovna bolezen kosti (PBK) pri novorojenčku tj. osteopenija, je bolezen z zmanjšano kostno maso. Nezadostne zaloge kalcija in fosfata ter hitra rast skeleta $v$ prvih mesecih življenja privedejo do motenj pri vgrajevanju mineralov $v$ organski kostni matriks, ki se kopiči v nemineralizirani obliki (osteomalacija) $(1,2)$.

Pojavnost (incidenca) osteopenije se je $v$ zadnjih letih povečala predvsem na račun povečanega preživetja ekstremno nedonošenih otrok in otrok z zelo nizko porodno težo. $V$ treh retrospektivnih raziskavah so pojavnost ocenili na 2-25\%. Kar polovica (50\%) otrok s porodno težo $<1000 \mathrm{~g}$ in $23-32 \%$ otrok s porodno težo $<1500 \mathrm{~g}$ naj bi imeli znižano mineralno gostoto (3).

Osteopenija se običajno osteopenija pojavi med 6. in 16. tednom po rojstvu, a pred 6. mesecem korigirane starosti. Pogosto ne povzroča nikakršnih simptomov in jo odkrijemo naključno ob najdbi zlomov reber na klasičnem rentgenskem posnetku pljuč $(4,5)$.

Znižana mineralna kostna gostota se pojavlja tudi pri donošenih novorojenčkih z dejavniki tveganja, vendar se $v$ nadaljevanju prispevka osredotočamo na PBK pri nedonošenih novorojenčkih.

\section{Razvoj kosti in mineralizacija skeleta pri plodu}

Kost je aktivno tkivo, ki ga sestavljajo celice (osteoblasti in osteoklasti) ter organski matriks, ki je sestavljen pretežno iz kolagena in kristalov kalcijevega hidroksiapatita. Sestavljena je iz kortikalne kostnine in iz trabekularne kostnine. Za trabekularno kostnino je značilna velika aktivnost kostne pregradnje, zato pri trabekularni kostnini spremembe kostne mase opazimo prej kot pri kortikalni kostnini. V kosti vseskozi potekata razgradnja in tvorba nove kostnine. Zreli osteoklasti, ki se naselijo na površini stare kosti, jo razgradijo in nato propadejo, na njihovo mesto pa se naselijo zreli osteoblasti in tvorijo organski matriks, ki kasneje mineralizira. Osteoklasti in osteoblasti morajo delovati usklajeno in v ravnovesju. Če je razgradnja kosti večja od izgradnje kosti, lahko pride do osteopenije oziroma osteoporoze (2).

Skelet se pri plodu prične razvijati zgodaj $v$ nosečnosti s proliferacijo in diferenciacijo hrustančnih prekurzorjev in napredujočo osifikacijo. Procese uravnavajo hormoni (rastni hormon in parathormon), citokini in vitamini (A, C, D) (3).

Za ustrezno mineralizacijo skeleta pri plodu, ki je najbolj intenzivna v tretjem trimesečju nosečnosti, so potrebni zadostne količine beljakovin in mineralov ter primeren energijski vnos. Minerali - predvsem kalcij in fosfor prehajajo $v$ plod $z$ aktivnim transportom preko posteljice; prenos je stabilen in neodvisen od prehranskega stanja matere. Tako sta plazemska raven kalcija in plazemska raven fosfata pri plodu višji kot po rojstvu; opisujejo, da sta $v$ drugem trimesečju nosečnosti za kar 20 \% višji kot pri materi. Prirast kalcija pri plodu je $v$ zadnjem trimesečju nosečnosti $100-120 \mathrm{mg} / \mathrm{kg} / \mathrm{dan}$, prirast fosforja pa $50-65 \mathrm{mg} / \mathrm{kg} / \mathrm{dan}(2,3)$.

Visok prenos mineralov $z$ matere na plod je povezan z nizko ravnijo paratiroidnega hormona (PTH), kalcitriola in spolnih steroidov pa tudi z visoko koncentracijo kalcitonina in s proteinom povezanega PTH (PTHrP) (angl. PTH-related protein). Zlasti receptorji za zaznavanje kalcija (CaSR) (angl. calcium sensing receptors) ohranjajo nizko raven PTH kot odziv na visoko raven kalcija $v$ serumu ploda. Nizka raven kalcitriola pri plodu je verjetno posledica zaviranja plodove ledvične $a$-hidroksilaze zaradi nizke ravni PTH, rastnega dejavnika fibroblasta-23 (FGF23), visokih ravni kalcija in fosfata ter povečane aktivnosti katabolnega encima 24-hidroksilaze. Visoka aktivnost 24-hidroksilaze v posteljici povzroči pretvorbo 25-hidroksivitamina $D$ v 24, 25-dihidroksivitamin $D$, ki se ne more pretvoriti v kalcitriol. Čeprav lahko humani horionski gonadotropin, pridobljen iz posteljice, in gonadotropini ploda iz hipofize spodbudijo nastajanje spolnih steroidov s pomočjo spolnih žlez, serumske ravni testosterona in estradiola ostanejo nizke do konca nosečnosti pri obeh spolih. Kalcitonin pri plodu nastaja v ščitnici in posteljici; njegova raven pri plodu je približno dvakrat višja kot raven kalcitonina v materinem obtoku. Visoke vrednosti kalcitonina ugodno vplivajo na odlaganje mineralov. PTHrP, ki ga proizvajajo hondrociti in perihondrijske celice, ima aditivno vlogo s PTH pri uravnavanju kalcija in fosfata ploda. Prav tako nastaja znotraj preosteoblastov in osteoblastov ter spodbuja nastajanje kosti.

Nasprotno od potreb po mineralih je glavni vir 25-hidroksivitamina $D$ za plod serumska raven vitamina pri materi; od tega je odvisen tudi novorojenček, dokler ne prične prejemati vitamina $D$ iz prehrane ali iz prehranskih dodatkov $(2,3,5)$.

Stanja, kot so preeklampsija, horioamnionitis in genetske motnje, ki prizadenejo delovanje posteljice, imajo za posledico zmanjšan prenos fosfata in kalcija preko posteljice in s tem slabšo mineralizacijo skeleta pri plodu. Mehanske sile, ki se ustvarijo pri gibanju ploda proti uporu stene maternice, spodbujajo rast kortikalne kosti (6).

\section{Mineralna homeostaza po rojstvu}

Po rojstvu pride do hitrih sprememb v oskrbi z minerali, hormonskem okolju in mehanskem stresu. $V$ skeletu pride do pomembnih prilagoditvenih procesov na zunajmaternično okolje. $S$ prekinitvijo popkovine se ustavi prenos kalcija in fosforja, zato se raven celokupnega ioniziranega kalcija hitro zmanjšuje in 16 ur po rojstvu doseže raven 
1,0-1,2 mmol/l, medtem ko koncentracija parathormona v prvih 24-48 urah po rojstvu narašča. Hkrati se zaradi vzdrževanja homeostaze kalcija poveča aktivnost osteoklastov, povečuje pa se tudi aktivnost osteoblastov, ki povzroča tvorbo nove kosti. Novorojenček po rojstvu postane odvisen od intestinalne absorpcije kalcija, zalog kalcija v kosteh in reabsorpcije kalcija v ledvicah ter na ta način v času kontinuiranega razvoja kosti vzdržuje normalne koncentracije tega minerala v krvi (2).

Izsledki raziskave, $v$ kateri so merili mineralno kostno gostoto $z$ dvoenergijsko rentgensko absorpciometrijo $v$ prvih tednih po rojstvu pri donošenih in nedonošenih otrocih, kažejo, da je hitrost rasti kosti v prvih tednih po rojstvu relativno višja kot mineralni prirast, kar vodi do stalnega zmanjševanja kostne gostote; proces imenujemo fiziološka osteopenija dojenčka $(9,10)$. Osteopenija v otroštvu je opredeljena kot kostna gostota med -1 SD in -2 SD. Dokazali so, da se mineralna kostna gostota $v$ prvih mesecih po rojstvu zmanjša za $30 \%$, pri čemer ostaja nerešeno vprašanje, ali gre tudi za osteoporozo, ki je opredeljena kot vrednost < -2 SD ob prisotnosti vsaj enega zloma. Postopno, po nekaj tednih ali mesecih, se vsebnost mineralov $v$ kosti povečuje in kostna masa se poveča. Če je ravnotežje med rastjo in mineralizacijo kosti porušeno do te mere, da pride do sistemskega zmanjšanja kostne mase, ki se mu pridružijo še arhitekturne spremembe kosti, se poveča krhkost kosti in $s$ tem tudi tveganje za zlome. Pri nedonošenčkih je zaradi pomanjkanja mineralov, večje občutljivosti na poporodne spremembe in izpostavljenosti dejavnikom tveganja zmanjšana tudi mineralizacija kosti (2).

\section{Pojavnost osteopenije pri nedonošenčkih}

Pojavnost PBK je na osnovi razpoložljive literature težko natančno določiti, delno zaradi razlik v terminologiji in delno zaradi razlik $v$ diagnostičnih merilih. Pri pregledu radioloških dokazov o PBK pri nedonošenčkih s porodno maso $1000 \mathrm{~g}$ se je pojavnost s približno $50 \%$ v letu 1987 zmanjšala na približno $15 \%$ v letu 2009. Zmanjšanje gre verjetno na račun splošno izboljšane oskrbe nedonošenčkov, zlasti z obogatitvijo materinega mle$k a$ in uporabo posebnega prilagojenega mleka za nedonošenčke, ki so dodaten vir kalcija in fosfata. Pojavnost osteopenije pri nedonošenčkih je obratno sorazmerna z nosečnostno starostjo (7-9).

\section{Dejavniki tveganja}

Dejavnikov tveganja za razvoj osteopenije pri nedonošenčku je veliko in so pogosto tesno povezani. Tveganje osteopenije je povečano pri nedonošenčkih, pri katerih je prišlo do zakasnitve pri vzpostavitvi enteralne prehrane in so bili dolgo odvisni od popolne parenteralne prehrane. Tveganje za hudo presnovno bolezen kosti je večje tudi ob pomanjkljivem vnosu mineralov pri boleznih, ki zmanjšujejo resorpcijo iz prebavil. Absorpcija kalcija iz prebavil je odvisna od razpoložljivosti kalcija in razpoložljivosti vitamina D v prehrani. Boljša je pri prehranjevanju z materinim mlekom kot pri prehranjevanju s prilagojenim mlekom, čeprav ima materino mleko v primerjavi s prilagojenim mlekom manjšo vsebnost kalcija. Fosfor se dobro absorbira iz obeh vrst mleka. Osteopenija je pogosta tudi pri otrocih $z$ intrauterinim zastojem rasti, saj kronična okvara posteljice spremeni transport fosfata in vpliva na spremenjeno presnovo kosti pri plodu. Nezadostna mineralizacija kosti pri nedonošenčkih je povezana s pridruženimi bolezenskimi stanji, kot so sepsa, bronhopulmonalna displazija, intraventrikularna krvavitev, živčno-mišične bolezni, povezane $z$ dolgotrajno imobilizacijo, acidoza, nekrotizirajoči enterokolitis, sindrom kratkega črevesa, holestaza in slaba prehranjenost matere. Uporaba zdravil, kot so diure- tiki (npr. furosemid), metilksantini (npr. kofein citrat) in kortikosteroidi, povečajo tveganje za nezadostno mineralizacijo kosti. Diuretiki, npr. furosemid, lahko povzročijo, da se z urinom pospešeno izločajo minerali, ki so potrebni za kostno mineralizacijo. Kortikosteroidi zavirajo tvorbo kosti in pospešujejo njeno razgradnjo. Na zmanjšanje tvorbe kosti delujejo preko zmanjševanja števila osteoblastov in zaviranja njihovega delovanja. Kortikosteroidi povzročajo tudi slabšo absorpcijo kalcija v črevesu in povečujejo njegovo izločanje skozi ledvice. Nedavno so dokazali tudi, da na presnovo v kosti in mineralno kostno gostoto pomembno vplivajo tudi genetski dejavniki. Raziskali so polimorfizme $v$ več kandidatnih genih in analizirali njihovo vlogo pri razvoju osteoporoze. Število kandidatnih genov se še vedno povečuje, za oceno njihovega vpliva na kostno maso pa bodo potrebne genetske raziskave na velikih populacijah $(2,6,10)$.

Plod se v maternici vseskozi giblje proti uporu, ki ga predstavlja stena maternice. Po rojstvu pri gibanju komponente upora ni več, s čimer se zmanjša obremenitev kosti. Komponenta gibanja proti uporu primanjkuje predvsem nedonošenčkom $v$ inkubatorjih, saj so zaradi zmanjšanja stresnih dogodkov deležni le minimalne taktilne stimulacije. Mehanska stimulacija gibanja je manjša tudi zaradi uporabe protibolečinskih zdravil in pomirjeval. S spodbujanjem kostno-mišičnega sistema pri nedonošenčkih izboljšamo mišično moč in s tem funkcionalno moč dolgih kosti. Kratke gibalne vaje (angl. range-of-motion, ROM) povečujejo mineralno kostno maso in zmanjšujejo mineralno gostoto kosti po rojstvu pri nedonošenčkih (2).

\section{Klinična slika}

Osteopenija pri nedonošenčku se običajno pojavi med 6 . in 16. tednom po rojstvu, a pred 6. mesecem korigirane starosti. Nedonošenčki s PBK nima- 
jo nikakršnih simptomov, vse dokler ne nastopijo zapleti. Pri rednem presejanju so običajno zvišane vrednosti biokemijskih kazalnikov in serumska vrednost kostne alkalne fosfataze. Radiološke značilnosti ugotavljamo pozneje in vključujejo osteopenijo (izpran videz in stanjšani kortikalni deli kosti na radiogramu). Če osteopenije ne zdravimo, se pojavijo patološki zlomi. Ob ustrezni prepoznavi in zdravljenju se $s$ klasično klinično sliko rahitisa (povečanje velike mečave, široko razmaknjeni lobanjski šivi, kraniotabes, zadebelitev kostno-hrustančnih stikov) danes srečamo zelo redko. Zlomi se kažejo z bolečino pri ravnanju z novorojenčkom ter oteklino in deformacijo na mestu zloma, a jih pogosto lahko naključno opazimo na rentgenskih posnetkih zaradi drugih indikacij. Prava pojavnost zlomov trenutno ni znana, a jo ocenjujejo na 17-34 \%. Običajno zlome ugotavljamo na dolgih kosteh oziroma rebrih. Radiološko vidni zlomi reber so bili prisotni pri samo 7 \% dojenčkov z izjemno nizko obporodno maso, ki so bili deležni sodobne neonatalne obravnave. Huda PBK lahko zaradi prekomerne mehkosti prsne stene povzroči tudi težave $z$ dihanjem $(4,10,12)$.

\section{Diagnostična opredelitev}

Ker PBK nedonošenčka pogosto ne povzroča nikakršnih simptomov, diagnostična opredelitev temelji na presejanju, ki zajema analizo biokemijskih označevalcev kostne presnove ter radioloških in ultrazvočnih najdb. Nedonošenčki z visokim tveganjem PBK so: i) nedonošenčki, rojeni pred 28. tednom nosečnosti in/ali s porodno maso < $1500 \mathrm{~g}$; ii) nedonošenčki, ki prejemajo popolno parenteralno prehrano več kot 4 tedne; in iii) nedonošenčki, ki dolgotrajno prejemajo diuretike ali kortikosteroidna zdravila. Spremljanje začnemo v starosti 4-6 tednov po rojstvu.
Biokemijski označevalci kostne presnove

\section{Serumski biomarkerji}

Koncentracijo kalcija v serumu skrbno uravnavajo hormoni in zato kot kazalnik mineralne kostne gostote (MKG) ni primerna. Za razliko od kalcija je nizka koncentracija serumskega fosfata povezana z nezadostnim vnosom fosforja in s povečanim tveganjem osteopenije (2).

Alkalna fosfataza (AF) je encim, ki ga izločajo osteoblasti, ledvice in črevo, in je kazalnik izgradnje kosti. Pri dojenčkih se $80 \%$ alkalne fosfataze izloča iz kosti; gre za t. i. skeletni izoencim (kostna AF). Koncentracija AF se poveča v prvih 2-3 tednih življenja, zlasti ob nezadostni zalogi mineralov. Povišana koncentracija AF je kazalnik nezadostne mineralizacije kosti, če jo hkrati potrdimo tudi s slikovnodiagnostičnimi metodami, s kvantitavno ultrazvočno preiskavo in z dvoenergijsko rentgensko absorpciometrijo (DXA). AF ima diagnostično vrednost $v$ kombinaciji z drugimi biokemijskimi kazalniki kostne zgradbe in razgradnje ter drugimi metodami za merjenje MKG. AF v kombinaciji s serumsko koncentracijo fosfata statistično značilno poveča občutljivost presejalnih metod in odkrivanja novorojenčkov s PBK (2).

$\checkmark$ raziskavah so dokazali, da lahko kronično pomanjkanje vitamina $D$ pri materi neugodno vpliva na razvoj skeleta pri plodu (2). Indikacije za oceno pomanjkanja vitamina $D$ pri nedonošenčku so: pomanjkanje vitamina $D$ pri materi, sindrom kratkega črevesa in bolezenska stanja, ki vplivajo na absorpcijo vitamina $D$, ter protiepileptično zdravljenje, ki lahko poveča katabolizem vitamina D (npr. fenobarbital) (3).

\section{Paratiroidni hormon}

Koncentracija paratiroidnega hormona (PTH) v serumu $>100 \mathrm{pg} / \mathrm{ml}$ pri nednošenčkih lahko kaže na PBK. Visoka koncentracija PTH ne kaže samo na sekundarni hiperparatiroidi- zem, ampak lahko skupaj z ledvično tubulno reabsorpcijo fosfata (TRP) razkrije osnovni vzrok hipofosfatemije. Tubulna resorpcija fosfata (TRP) določa delež filtriranega fosfata, ki se reabsorbira, in jo izračunamo kot razmerje med fosfatom in kreatininom v serumu in urinu $\left(U_{\text {fosfat }} / S_{\text {fosfat }} \times S_{\text {kreatinin }}\right.$ ' $\left.U_{\text {kreatinin }}\right)$. Nizka vrednost TRP ob visoki vrednosti PTH kaže na pomanjkanje kalcija in/ali vitamina $D$, medtem ko visoka vrednost TRP ob nizki ali normalni vrednosti PTH kaže na pomanjkanje fosfata (3). Serumski osteokalcin $(\mathrm{OC})$, protein kostnega matriksa, je označevalec aktivnosti osteoblastov in ga delno uravnava raven 1,25-dihidroksivitamina D. Pri velikem pretoku v kosti se koncentracija OC poveča. Kljub specifičnosti pa v prvih štirih mesecih življenja ni jasne povezave med koncentracijo $O C \mathrm{v}$ serumu in vsebnostjo mineralnih snovi v kosteh (5).

\section{Biomarkerji v urinu}

$Z$ ocenjevanjem izločanja kalcija in fosforja v urinu določamo ustreznost mineralizacije kosti. Izločanje kalcija $v$ urinu $>1,2 \mathrm{mmol} / \mathrm{l}$ in izločanje fosforja $v$ urinu $>0,4 \mathrm{mmol} / \mathrm{l}$ kažeta na pomembno zmanjšanje mineralne kostne gostote (2). Nedonošenčki, rojeni med 23. in 25. tednom nosečnosti, imajo znižan prag izločanja fosforja, kar se kaže s povečanim izločanjem fosforja v urinu tudi takrat, ko je vrednost serumskega fosfata znižana (10).

Hipofosfatemija, najpogostejša biokemijska sprememba, povezana s PBK, povzroča zmanjšano sproščanje PTH, kar poveča reabsorpcijo ledvičnega tubulnega fosfata. Zmanjšane vrednosti fosfata prav tako neposredno stimulirajo ledvično tubulno sintezo vitamina $D$, kar poveča črevesno absorpcijo kalcija. Tako pomanjkanje fosfatov moti ravnovesje kalcija, kar vodi v hiperkalcemijo, hiperkalciurijo in nefrokalcinozo. Normalna vrednost je 78-91\%, vrednost > $95 \%$ pa je pomemben kazalnik nezadostnega vnosa fosfatov. Tudi razmerja med kalcijem ali fosfatom in kreatininom v uri- 
nu so lahko koristni biomarkerji PBK. Čeprav so ta razmerja zelo odvisna od prehranskega vnosa, nanje vpliva tudi jemanje zdravil, kot sta furosemid in teofilin.

Potrebe po mineralih moramo določati z rednim biokemijskim nadzorom, ki naj se začne $v$ tretjem tednu kronološke starosti in vključuje serumske vrednosti kostne AF, fosfata in kalcija, raven $\mathrm{PTH} v$ plazmi, 25-hidroksi-vitamin D in urinske biomarkerje. Čeprav jasnih priporočil o pogostosti biokemijskega spremljanja ni, priporočajo spremljanje na dva tedna, odvisno od stopnje tveganja in prisotnosti dejavnikov tveganja.

\section{Radiološke preiskave}

Za ocenjevanje mineralizacije kosti pri nedonošenčkih uporabljamo različne radiološke preiskave (10).

Klasično rentgensko slikanje skeleta je slabo občutljiva metoda, saj spremembe v kosteh opazimo šele, ko je mineralizacija kosti zmanjšana za več kot $40 \%(2,10)$.

DXA je zlati standard za določanje MKG pri nedonošenčkih. Slabe strani DXA pri nedonošenčkih so potreba po transportu in sedaciji ter izpostavljenost majhnim količinam rentgenskega sevanja $(2,10)$.

V zadnjem času za merjenje mineralne kostne gostote vse bolj uporabljamo kvantitativno ultrazvočno metodo, ki je natančna, enostavna, neboleča in poceni ter bolnikov ne izpostavlja nevarnostim sevanja. Preiskava temelji na spremembi hitrosti in energije ultrazvočnih valov pri prehodu skozi kost (angl. speed of sound, SOS (m/s)). Hitrost in amplituda ultrazvočnih valov sta odvisni od fizikalnih lastnosti medijev (mineralna gostota, debelina korteksa, elastičnost in mikroarhitektura) in nista odvisni od lastnosti mehkih tkiv. Metoda nudi bistveno bolj popolno sliko trdnosti kosti kot izključno merjenje mineralne kostne gostote. Pri novorojenčkih merimo kostno gosto- to na tibialni kosti, rezultate meritev pa primerjamo s standardi za novorojenčke enake rase, nosečnostne starosti, spola in telesne teže ter jih izrazimo s standardnim odklonom od povprečja (angl. Z-score) $(2,6,10)$.

Podatki dosedanjih raziskav o uporabi kvantitativne ultrazvočne metode pri nedonošenčkih kažejo, da nima neželenih učinkov in je primerna za zaporedne meritve pri spremljanju stanja. Njena prednost je tudi, da lahko meritve izvajamo na različnih delih telesa, pri čemer se rezultati bistveno ne razlikujejo. Dokazali so povezavo med SOS in nosečnostno starostjo, saj je pri donošenih novorojenčkih vrednost SOS na račun bolj zrelih kosti višja kot pri nedonošenih novorojenčkih. Vrednost SOS se po rojstvu tako pri nedonošenih kot pri donošenih novorojenčkih postopno zmanjšuje. Poročila raziskav o povezavi med SOS in telesno maso ter SOS in biokemijskimi označevalci kostne gostote si nasprotujejo. Povezava med parametri kvantitativne ultrazvočne metode in DXA trenutno še ni dovolj raziskana (11).

\section{Preprečevanje in zdravljenje osteopenije pri nedonošenčku}

$\checkmark$ prvi vrsti je pomembno, da PBK preprečujemo z zmanjševanjem dejavnikov, ki vplivajo na nastanek bolezni (Tabela 1).

Potrebe nedonošenčkov so močno odvisne od posameznikove hitrost rasti in znašajo 1-4 mmol/kg/dan kalcija (40-160 mg/kg/dan) in 0,75-3 mmol/ $\mathrm{kg} /$ dan fosforja (23-93 $\mathrm{mg} / \mathrm{kg} / \mathrm{dan}$ ) z molskim razmerjem Ca:P 1,3:1. Evropsko združenje za otroško gastroenterologijo, hepatologijo in prehrano (ESPGHAN) pri parenteralni prehrani v prvem tednu življenja nedonošenčka predlaga molsko razmerje med kalcijem in fosfatom 0,8:1, kasneje pa 1,3:1 (Tabela 2). V raztopinah lahko uporabljamo anorganske kalcijeve soli (kalcijev klorid) ali organske kalcijeve soli (kalcijev glukonat, kalcijev glicerol-fosfat) in soli organskih fosfatnih spojin $(13,14)$. Priporočilo za vnos z enteralno prehrano pri nedonošenčkih in dojenčkih z nizko porodno maso je 120-140 mg/kg /dan kalcija in 60-90 $\mathrm{mg} / \mathrm{kg} /$ dan fosforja (Tabela 2) (15). Večje potrebe pri enteralnem vnosu kalcija so posledica dejstva, da se pri nedonošenčkih absorbira približno 50 $\%$ kalcija v prilagojeni mlečni formuli in do $70 \%$ kalcija v materinem mleku, medtem ko je absorpcija fosforja 70-90\%. Poleg tega vsebnost beljakovin in mineralov $v$ materinem mleku za potrebe nedonošenčka ni dovolj, zato svetujemo obogatitev materinega mleka in prilagojene mlečne formule za nedonošenčke vsaj do 36 . tedna nosečnosti in/ali $2000 \mathrm{~g}(16,17)$.

Upoštevati moramo, da različna bolezenska stanja vplivajo na homeostazo kalcija in fosforja ter lahko povečujejo tveganje PBK. Zato predlagajo, da je prehrana prilagojena posameznemu nedonošenčku (tj. individualizirana), pri čemer moramo tako pri enteralni kot pri parenteralni prehrani upoštevati optimalno razmerje med kalcijem in fosforjem.

Zvišana vrednost PTH v PBK stimulira pretvorbo 25-hidroksi-vitamin D v aktivno obliko 1,25-dihidroksi-vitamin D, kar lahko povzroči izčrpavanje 25-hidroksi-vitamina D. Zato poleg profilaktičnih odmerkov pri dokazanem pomanjkanju dodajamo visoke odmerke vitamina D, s čimer želimo koncentracijo 25-OHD vzdrževati nad ravnijo $75 \mathrm{nmol} / \mathrm{l}$. Na podlagi priporočil iz strokovne literature so slovenski neonatologi sprejeli smernice, da nedonošenčki prejemajo vitamin $\mathrm{D} v$ odmerku 800 IE/dan (4).

Pri otrocih s povišanimi vrednostmi PTH, ki nakazuje pomanjkanje kalcija, je smiselno oralno nadomeščanje kalcija z začetnimi odmerki 0,5 mmol/kg/ dan in postopno povečevanje do ravni 1-1,25 mmol/kg/dan v 2-3 odmerkih. Višji odmerki so potrebni pri hujši obli- 
ki PBK ter zelo visoki vrednosti plazemskega PTH in serumske koncentracije AF. Odmerek lahko zmanjšamo, če je raven kalcija nad normalno vrednostjo, vendar z nadomeščanjem kalcija ne smemo prenehati, dokler se plazemska vrednost PTH ne normalizira. Visoki odmerki kalcija predstavljajo tveganje nefrokalcinoze, a je ob prisotnosti normalne ali povišane vrednosti PTH tveganje zanemarljivo, saj PTH olajša aktivno tubulno resorpcijo kalcija.

Pri pomanjkanju fosforja zaradi zmanjšanega vnosa s hrano in/ali povečane izgube $z$ urinom vrednost PTH ni povišana, zato $\mathrm{PBK}$ zdravimo $z$ nadomeščanjem fosforja. Pri domnevnem pomanjkanju fosforja je potrebno previdno nadomeščanje, saj moramo zagotoviti, da razmerje med celokupnim enteralnim kalcijem in fosforjem ni spremenjeno v prid P. Relativni presežek fosforja bi se odražal z znižano vrednostjo ioniziranega kalcija in hiperparatiroidizmom (in nadaljnji izgubi fosforja $z$ urinom). Pred začetkom nadomeščanja fosforja moramo upoštevati vnos kalcija in fosforja $s$ hrano ter razmisliti o hkratnem nadomeščanju kalcija (4).

Pri preprečevanju osteopenije je pomembno tudi nefarmakološko zdravljenje. Gibanje ploda proti uporu stene maternice pripomore k primerni mineralni sestavi kosti in razvoju mišic. $S$ fizioterapijo skušamo zagotoviti potrebno stimulacijo, ki je bila izgubljena po prezgodnjem rojstvu. Priporočajo, da fizioterapijo v obliki pasivnega gibanja udov izvajamo približno 5-15 minut dnevno vsaj $4-8$ tednov $(3,5,10)$.

Po odpustu pri nedonošenčkih z nizko porodno maso $(<1500 \mathrm{~g})$ priporočamo sledenje kostne gostote s kvantitativnim ultrazvokom in merjenje ravni alkalne fosfataze $v$ serumu na 2-4 tedne. Če so vrednosti AF višje od $13,33-16,67 \mu \mathrm{kat} / \mathrm{l}$, je potreben dodatek mineralov. Prilagojene mlečne formule za nedonošenčke ali obogateno materino mleko priporočamo vsaj do 36. tedna postmenstruacijske starosti,

\begin{tabular}{|c|c|}
\hline Dejavnik tveganja & Mehanizem \\
\hline nedonošenost & - zmanjšana mineralizacija in utero \\
\hline nizka porodna teža & $\begin{array}{l}\text { - povezano z nedonošenostjo } \\
\text { - povezano s placentno insuficienco in zmanjšanim } \\
\text { aktivnim placentnim transportom mineralov in } \\
\text { utero }\end{array}$ \\
\hline zmanjšanje materinega estrogena & - povečano tvorjenje osteoklastov in resorpcija kosti \\
\hline manjša telesna dejavnost & $\begin{array}{l}\text { - povečana resorpcija kosti zaradi znižane } \\
\text { mehanske stimulacije in deformacije }\end{array}$ \\
\hline parenetralna prehrana & - omejen vnos kalcija in fosfata zaradi precipitacije \\
\hline glukokortikoidi & $\begin{array}{l}\text { - znižana absorpcija mineralov v črevesu } \\
\text { - neposreden učinek na kost (povečana resorpcija in } \\
\text { zmanjšano tvorjenje kosti) }\end{array}$ \\
\hline antacidi & - znižana absorpcija kalcija v črevesu \\
\hline diuretiki zanke & - povečane izgube kalcija v ledvicah \\
\hline kronična bolezen pljuč (BPD) & $\begin{array}{l}\text { - večje potrebe po energiji } \\
\text { - daljša uporaba diuretikov zanke in } \\
\text { glukokortikoidov }\end{array}$ \\
\hline nekrotizirajoči enterokolitis & $\begin{array}{l}\text { - daljši čas parenteralne prehrane } \\
\text { - slabše delovanje črevesa }\end{array}$ \\
\hline povečan vnos fosfata & $\begin{array}{l}\text { - neravnovesje med kalcijem in fosfatom s } \\
\text { sekundarnim hiperaparatiroidizmom in resorpcijo } \\
\text { kosti }\end{array}$ \\
\hline
\end{tabular}

TABELA 1. DEJAVNIKI TVEGANJA ZA PRESNOVNO BOLEZEN KOSTI NEDONOŠENČKOV. TABLE 1. RISK FACTORS FOR METABOLIC BONE DISEASE IN PRETERM INFANTS.

\begin{tabular}{|c|c|c|c|c|c|}
\hline & $\begin{array}{l}\text { PPP } \\
\text { prvi teden* }\end{array}$ & $\begin{array}{l}\text { Razmerje } \\
\mathrm{Ca}: \mathrm{P}\end{array}$ & $\begin{array}{l}\text { PPP od drugega } \\
\text { tedna naprej* }\end{array}$ & $\begin{array}{l}\text { Razmerje } \\
\mathrm{Ca}: \mathrm{P}\end{array}$ & $\begin{array}{l}\text { Enteralna } \\
\text { prehrana }^{+}\end{array}$ \\
\hline Kalcij & $\begin{array}{l}32-80 \mathrm{mg} / \mathrm{kg} / \\
\mathrm{dan} \\
(0,8-2 \mathrm{mmol} / \\
\mathrm{kg} / \mathrm{dan})\end{array}$ & & $\begin{array}{l}64-140 \mathrm{mg} / \mathrm{kg} / \\
\mathrm{dan} \\
(1,6-3,5 \mathrm{mmol} / \\
\mathrm{kg} / \mathrm{dan})\end{array}$ & & $\begin{array}{l}120-140 \mathrm{mg} / \mathrm{kg} / \\
\text { dan }\end{array}$ \\
\hline Fosfat & $\begin{array}{l}31-62 \mathrm{mg} / \mathrm{kg} / \\
\text { dan } \\
(1-2 \mathrm{mmol} / \mathrm{kg} / \\
\text { dan) }\end{array}$ & $0,8: 1$ & $\begin{array}{l}50-108 \mathrm{mg} / \mathrm{kg} / \\
\mathrm{dan} \\
(1,6-3,5 \mathrm{mmol} / \\
\mathrm{kg} / \mathrm{dan})\end{array}$ & $1,3: 1$ & $60-90 \mathrm{mg} / \mathrm{kg} / \mathrm{dan}$ \\
\hline Vitamin D & $400 \mathrm{IU} / \mathrm{dan}$ & & $800 \mathrm{IU} / \mathrm{dan}$ & & $800 \mathrm{IU} / \mathrm{dan}$ \\
\hline
\end{tabular}

TABELA 2. POTREBE PO KALCIJU, FOSFATU IN VITAMINU D PRI NEDONOŠENČKIH $\left(13^{*}, 14^{+}\right)$. TABLE 2. CALCIUM, PHOSPHATE AND VITAMIN D NEEDS IN PRETERM INFANTS $\left(13^{*}, 14^{+}\right)$. Legenda: Ca - kalcij; P - fosfat; PPP - popolna parenteralna prehrana. 
ob nezadostnem pridobivanju telesne mase pa do 6. meseca. Koliko časa dodajamo minerale, je še vedno predmet razpravljanja in $v$ večini odvisno od individualnih potreb (5).

\section{Zaključek}

Osteopenija je pomemben problem pri nedonošenčkih. Zato moramo poskrbeti za preprečevanje, zgodnjo prepoznavo ter optimalni parenteralno in enteralno prehrano. Zdravljenje poleg optimalne prehrane vključuje tudi dodatke kalcija, fosforja in vitamina D ter ustrezno fizioterapevtsko obravnavo.

\section{Literatura}

1. Wood CL, Wood AM, Harker C, Embleton ND. Bone mineral density and osteoporosis after preterm birth: the role of early life factors and nutrition. International J of Endocrin 2013; 2014(Special): 1-7.

2. Soltirovska Šalamon A, Paro Panjan D. Osteopenija pri novorojenčku: možnosti diagnosticiranja in zdravljenja. 25. Derčevi dnevi - Zbornik predavanj. Ljubljana: Univerza v Ljubljani, Medicinska fakulteta, Katedra za pediatrijo 2013: 102-10.

3. Rustico SR, Calabria AC, Garber SJ. Metabolic bone disease of prematurity. Journal of Clinical \& Translational Endocrinology 2014; 1(3): 85-91.

4. Chinoy A, Mughal MZ, Padidela R. Metabolic bone disease of prematurity: causes, recognition, prevention, treatment and lond-term consequences. ADC Fetal Neonatal Ed 2019; 104(5):

F560-6.

5. Faienza MF, D'Amato E, Natale MP, Grano M, Chiarito M, Brunetti G, D'Amato G. Metabolic bone disease of prematurity: diagnosis and management. Frontiers in pediatrics 2019; 7(143). Dosegljivo na: https://www.frontiersin. org/articles/10.3389/fped.2019.00143/full

6. Rehman UM, Narchi Hassib. Metabolic bone disease in the preterm infant: Current state and future directions. World J of Metodol 2015; 5(3): 115-21.

7. Lyon AJ, Mclntosh N, Wheeler K, et al. Radiological rickets in extremely low birthweight infants. Pediatr Radiol 1987; 17: 56.

8. Mitchell SM, Rogers SP, Hicks PD, et al. High frequencies of elevated alkaline phosphatase activity and rickets exist in extremely low birth weight infants despite current nutritional support. BMC Pediatr 2009; 9: 47.

9. Abrams SA Committee on Nutrition. Calcium and vitamin $d$ requirements of enterally fed preterm infants. Pediatrics 2013; 131: e1676-83. 10. Nallagonda S, Nallagonda M, Deorukhkar A. Metabolic bone disease of prematurity - an overiview. Peadiatrics and Child Health 2017; 27(1): 14-7.

11. Tong L, Gopal-Kothandapani JS, C. Offiah A. Feasibility of quantitative ultrasonography for the detection of metabolic bone disease in preterm infants - systematic review. Pediatric Radiology 2018; 48: 1537-49.

12. Chin LK, Doan J, Teoh YSL, Stewart, Forrest A, Simm PJ. Outcomes of standardised approach to metabolic bone disease of prematurity. J of Pediatr and Child Health 2018; 54(6): 665-70.

13. Mulla S, Stirling S, Cowey S, et al. Severe hypercalcaemia and hypophosphataemia with an optimised preterm parenteral nutrition formulation in two epochs of differing phosphate supplementation. Arch Dis Child Fetal Neonatal Ed 2017; 102: F451-5.

14. Mihatsch W, Fewtrell M, Goulet O, et al. ESPGHAN/ESPEN/ESPR/CSPEN guidelines on pediatric parenteral nutrition: Calcium, phosphorus and magnesium. Clin Nutr 2018; 37: 2360-5. 15. Agostoni C, Buonocore G, Carnielli VP, et al. Enteral nutrient supply for preterm infants: commentary from the European Society of Paediatric Gastroenterology, Hepatology and Nutrition Committee on Nutrition. J Pediatr Gastroenterol Nutr 2010; 50: 85-91.

16. Koletzko B, Poindexter B, Uauy R. Nutritional care of preterm infants: scientific basis and practical guidelines, 2014.

17. Abrams SA. Committee on Nutrition. Calcium and vitamin d requirements of enterally fed preterm infants. Pediatrics 2013; 131: e1676-83.
Nina Majoranc, dr. med.

Pediatrična klinika, Univerzitetni klinični center, Bohoričeva 20, 1000 Ljubljana, Slovenija

\section{doc. dr. Aneta Soltirovska Šalamon,} dr. med.

kontaktna oseba / contact person: Klinični oddelek za neonatologijo, Pediatrična klinika, Univerzitetni klinični center Ljubljana, Bohoričeva 20, 1000 Ljubljana, Slovenija e-naslov: aneta.soltirovska@kclj.si

prispelo / received: 13. 10. 2020

sprejeto / accepted: 11. 8. 2021

Majoranc N, Soltirovska Šalamon A,

Osteopenija nedonošenčka. Slov Pediatr 2021; 28(3): 123-129. https://doi.org/10.38031/ slovpediatr-2021-3-04. 